\title{
クッシング病に対する経蝶形骨洞手術 一特に残存下垂体前葉機能について一
}

\author{
桑山 明夫・景山 直樹 · 中根 藤七 \\ 渡辺 正男・高野橋正好
}

\section{Transsphenoidal Adenomectomy in Cushing's Disease, with Special Emphasis on Residual Adenohypophysial Function}

\author{
Akio Kuwayama, Naoki Kageyama, Toshichi Nakane, \\ Masao Watanabe and Masayoshi Takanohashi \\ Department of Neurosurgery, Nagoya University, Nagoya 466
}

\begin{abstract}
Summary
The success of transsphenoidal adenomectomy in 10 patients with Cushing's disease was judged by the residual adenohypophysial function. Surgery was indicated mainly by endocrinological results. Radiologically, the sella turcica was slightly enlarged in three cases, which had all macroadenomas with the diameter of more than $10 \mathrm{~mm}$. The other seven had microadenomas 3-7 mm in diameter with normal-sized sella. In two cases, localized bulging of the floor was confirmed by polytomography. In one case the adenoma was far away from the midline and was completely buried in the lt-lateral wing. All the others were located in the center of the adenohypophysis. Complete adenomectomy involving adjacent normal tissue rcsulted in amazing clinical improvement with hypoadrenocortisolism in all cases except one in which the surgical maneuvers appeared incomplete.

The preoperative basal levels of plasma ACTH were $135.6 \pm 27.5 \mathrm{pg} / \mathrm{ml}(\mathrm{M} \pm \mathrm{S}$.E.) and responsiveness to insulin hypoglycemia was absent in all cases with a loss of diurnal rhythmicity, whereas conspicuous ACTH responsiveness to 8-lysine vasopressin (LVP) was observed in most cases, as shown by the increase from 107.8 \pm 23.8 to $362.5 \pm 98.7 \mathrm{pg} / \mathrm{ml}$. The postoperative basal plasma ACTH levels dropped to $24.6 \pm 11.3 \mathrm{pg} / \mathrm{ml}$ and their responses to LVP became blunted in most cases with a peak value of $57.0 \pm 21.4 \mathrm{pg} / \mathrm{m} l$, whereas hypoglycemic responses became positive in most cases, as shown by the peak value of $62.7 \pm 12.6 \mathrm{pg} / \mathrm{m} l$. The diurnal rhythmicity of plasma ACTH and cortisol became apparent in all five cases examined 6 months after surgery.

Preoperative plasma GH responses to insulin hypoglycemia were impaired in all cases and the peak value did not exceed $10 \mathrm{ng} / \mathrm{m} l$ in any case. Postoperatively, the peak value significantly increased at an average of $7.9 \pm 3.9 \mathrm{ng} / \mathrm{m} l$ (M \pm S.D.) and in four cases it exceeded $10 \mathrm{ng} / \mathrm{ml}$. TSH responses to TRH and LH to LH-RH were also significantly improved postoperativcly. FSH responses to LH-RH and PRL to TRH did not change significantly.

These results support the concept that ACTH hypersecretion of pituitary adenoma is the primary abnormality in Cushing's disease and hypothalamic CRF activity is suppressed by long-standing hypercortisolism. Furthermore, the hypothalamic-pituitary functions of other anterior pituitary hormones such as GH, TSH and LH are impaired by hypercortisolism and could be returned to normal by selective transsphenoidal adenomectomy. We
\end{abstract}

\section{名古屋大学媨神経外科}

[連絡先： $\bar{\top} 466$ 名古屋市昭和区鶴舞町 65 , 名古屋大学腷神経外科, 桑山明夫]

1980年1月 8 日 受稿 
conclude that this operation is the first choice of treatment of Cushing's disease for clinical and endocrinological improvements.

Key words: Cushing's disease, diurnal rythm, insulin, vasopressins, anterior pituitary hormones

\section{I はじめに}

ごく最近まで, クッシング病の主病因は，下垂体ホル モン分泌調節する視床下部，またはその上位中枢の機 能異常によるものではないかと推察されてきた。 その主 たる理由としては，大部分のクッシング病症例では，下 垂体腺缠の存在を示唆するごとき明らかなトルコ鞍の形 愳異常を認めず，その内分泌異常も ACTH およびェー チゾールの過剩分泌のみでなく，GH，TSH，LHなど他 の下垂体前葉ホルモン分泌機能障害も高嚬度に認められ ることなどである(147日)，しかしながら経蝶形骨洞法に よる手術症例の増加に伴い，トルコ鞍の形態異常の有無 にかかわらずその大部分の症例で下垂体腺腫の存在が確 認され，腺腫摘除により，他のホルモン産生腺腫と同様 にあるいはそれ以上に，著しい臨床症状の改善をもたら しうる事実が判明し，腺腫摘除により完治しうる期待む 高まってきた。したがって，この下垂体腺腫摘除術が， クッシング病に対する治療法として今後さらに高い評価 を得るためにも，またをの病態生理をより媣く理解する 上でも，術能・術後にわたる内分泌機能動態の検索は必 要不可欠と思われる，今回，我々はクッシング病手街症 例10例につき以上の観点より検討したので，その手術所 見と併せ報告する。

\section{II汸前の検查所見}

症例は昭和52年 1 月より同53年 5 月までに手術を施行 した女性 9 例，男性 1 例で，年令汢13 52才，平均 35.8 才であった. これらの症例のうち1例 (Case 8) で恃, すでに副腎の互全摘出術と下垂体照射の併用を受汁症状 一時宽解後再発したものである. 症状初発後当科受診ま での罹病期間は 6 力月加ら最長 13 年で, 平均 3 年 4 力月 であった。

1. 内分泌検査所㫕

1）視休下部一下垂体一副腎皮質系機能

多くの成例では，爬中17-OHCS 汇デキサメサゾン少 量 ( $2 \mathrm{mg} / \mathrm{day}$ )で汢抑制不十分, 大量 ( $8 \mathrm{mg} / \mathrm{day})$ では 部分抑制を示した。しかしながら，2 例ではデキサメサ

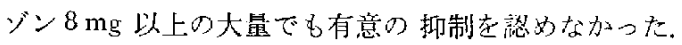
メトピロン負荷試験では，1例定除き全例上も100\%以 上の疛中17-OHCS の増加反応瑟奻た，術前の血獎 $\mathrm{A}$ $\mathrm{CTH}$ 值注 $59 \sim 260 \mathrm{pg} / \mathrm{m} l$, 平均 $135.6 \pm 27.5 \mathrm{pg} / \mathrm{ml}$ (M
土S.E.) であり，4例では常に $100 \mathrm{pg} / \mathrm{m} l$ 以下の正常範 用内であった．血漿 ACTH 执よびューチゾールの明ら かな日内リズムは全例で消失していた，インシュリン低 血糖 $(0.1 \sim 0.15 \mathrm{U} / \mathrm{kg}$, i.v.) に対与る血洯 ACTH の 分泌堌加反応は 6 例で検討した（Table 1，Fig. 2).投与 前の平均血獎 ACTH 值は102.8 $115.0 \mathrm{pg} / \mathrm{ml}$ であった が，インシュリン負荷後の頂值の平均は101.5 $23.4 \mathrm{pg} /$ $\mathrm{m} l$ ですり，有意の增加反应寺さなかった，個々の症例 についてみても，頂值が基礎値の50\%以上の増加孛認め た症例は 1 例もなかった。 これに反し，リジンバゾプレ シン (LVP) 投与後は (10 U, i.m.) 6例全例で50\%以 上の血衤 ACTH 值の分泌増加索認めた（Table 1, Fig. 3 ). すなわら投与前の平均基礎值は $107.8 \pm 23.8 \mathrm{pg} / \mathrm{m} l$ であったが，LVP 投与後の頂値は $362.5 \pm 98.7 \mathrm{pg} / \mathrm{ml}$ と 明らかな増加反応を認めた。

2）他の下垂体前葉機能

$\mathrm{ACTH}$ 系以外の下垂体前葉ホルモン分泌譏能に関 し ては，インシュリン低血糖に対する GH，TRH 負荷 (500 $\mu \mathrm{g}$ ，i.v.) に対市る TSH ц PRL, LH-RH (100 $\mu \mathrm{g}$, i.v.) に対士る LH，FSH の分泌機能を検討した

(Table 2)，インシュリン低血糖刺激に対する血漿 $\mathrm{GH}$ の分泌増加反応は，高度の精神障害のため施行不可能で あった 1 例を除く9例に施行した。 血漿 $\mathrm{GH}$ 基礎值仕 $0.8 \sim 2.8 \mathrm{ng} / \mathrm{m} l$ (平均 $1.6 \pm 0.6 \mathrm{ng} / \mathrm{ml}, \mathrm{M} \pm \mathrm{S}$. D.) ヶ゙, インシュリン負荷後の頂值は平均 $2.7 \pm 1.9 \mathrm{ng} / \mathrm{ml}$ とわず かに増加したが，10 $\mathrm{ng} / \mathrm{m} l$ 以上の正常增加区応埾示した のは，1例も認めなかった，尖前の血脽 TSH 值は10例

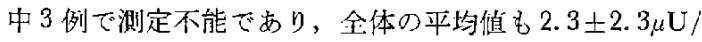
$\mathrm{m} l$ と低值を示した. TRH 負荷後の頂值も5.4 $43.5 \mu \mathrm{U} /$ $\mathrm{m} l$ と低值であり, $10 \mu \mathrm{U} / \mathrm{m} l$ 以上の明らかな増加反応 走示したの江 2 例のみですった。閉経後女子症例 (Case $2,5,7$ ) 除く 7 例 0 血中 $\mathrm{LH}, \mathrm{FSH}$ 平均基礎值は， それぞ扎 $6.9 \pm 5.9 ， 10.2 \pm 4.5 \mathrm{mIU} / \mathrm{m} l$ であり，LHRH 負荷後の頂值はそれそれ 37.5 土35.7，17.9土10.9 $\mathrm{mIU} / \mathrm{ml}$ であった. LH の頂值が $30 \mathrm{mIU} / \mathrm{m} /$ 以下の高度

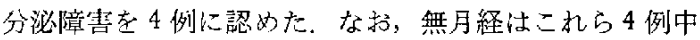
の3 例を含为 4 例に認めら扎た，術前の血漿 PRL 基礎 值は 8 例で検討したが，全例とも25 $\mathrm{ng} / \mathrm{m} /$ 以下の正常範 囲内であった。

\section{2. 頭部 $\mathbf{X}$ 線検查所見}

嘼部単純写上, 軽度のトルコ鞍容積の増大と balloon- 

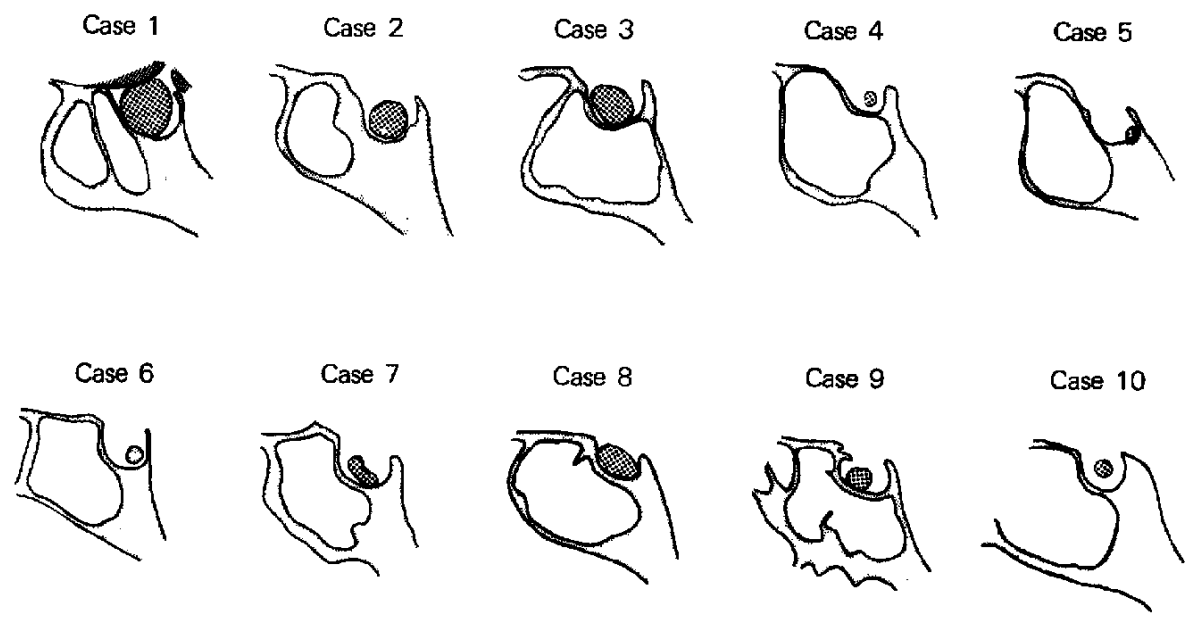

Fig. 1 Size of the adenoma and its location is schematically presented on the trace of the sella turtica.

Table 1 Plasma cortisol and ACTH responses to insulin hypoglycemia and 8-lysine vasopressin before and after transsphenoidal adenomectomy in patients with Cushing's disease.

\begin{tabular}{|c|c|c|c|c|c|c|c|c|c|c|c|}
\hline \multirow{3}{*}{$\begin{array}{c}\text { Patients } \\
\text { No. }\end{array}$} & \multirow[b]{3}{*}{ Age } & \multirow[b]{3}{*}{ Sex } & \multirow{3}{*}{$\begin{array}{l}\text { Pre-OP } \\
\text { Post-OP }\end{array}$} & \multicolumn{4}{|c|}{ Cortisol $(\mu \mathrm{g} / \mathrm{d} l)$} & \multicolumn{4}{|c|}{ ACTH $(\mathrm{pg} / \mathrm{ml})$} \\
\hline & & & & \multicolumn{2}{|c|}{ Insulin } & \multicolumn{2}{|c|}{ Vasopressin } & \multicolumn{2}{|c|}{ Insulin } & \multicolumn{2}{|c|}{ Vasopressin } \\
\hline & & & & Basal & Peak & Basal & Peak & Basal & Peak & Basal & Peak \\
\hline 1. & 27 & F & $\left\{\begin{array}{l}\text { Pre } \\
\text { Post }\end{array}\right.$ & $\begin{array}{r}24.5 \\
9.9\end{array}$ & 17.5 & & & $\begin{array}{r}158 \\
48\end{array}$ & & & \\
\hline 2. & 51 & F & $\left\{\begin{array}{l}\text { Pre } \\
\text { Post }\end{array}\right.$ & $\begin{array}{r}35.0 \\
6.9\end{array}$ & $\begin{array}{l}38.0 \\
11.7\end{array}$ & 7.0 & 12.6 & 223 & & & \\
\hline 3. & 43 & $\mathbf{F}$ & $\left\{\begin{array}{l}\text { Pre } \\
\text { Post }\end{array}\right.$ & $\begin{array}{l}24.0 \\
14.9\end{array}$ & 14.1 & 11.6 & 37.0 & $\begin{array}{r}260 \\
68\end{array}$ & 75 & & \\
\hline 4. & 13 & $\mathrm{~F}$ & $\left\{\begin{array}{l}\text { Pre } \\
\text { Post }\end{array}\right.$ & $\begin{array}{l}53.0 \\
28.0\end{array}$ & $\begin{array}{l}40.0 \\
39.0\end{array}$ & 51.0 & 85.0 & $\begin{array}{l}98 \\
54\end{array}$ & & 68 & 110 \\
\hline 5. & 52 & F & $\left\{\begin{array}{l}\text { Pre } \\
\text { Post }\end{array}\right.$ & $\begin{array}{c}30.4 \\
\text { UD }\end{array}$ & $\begin{array}{c}20.5 \\
\text { UD }\end{array}$ & $\begin{array}{l}20.4 \\
\mathrm{UD}\end{array}$ & $\begin{array}{l}31.4 \\
\text { UD }\end{array}$ & $\begin{array}{r}92 \\
\text { UD }\end{array}$ & $\begin{array}{l}62 \\
23\end{array}$ & $\begin{array}{r}92 \\
\text { UD }\end{array}$ & $\begin{array}{r}170 \\
14\end{array}$ \\
\hline 6. & 31 & $\mathrm{~F}$ & $\left\{\begin{array}{l}\text { Pre } \\
\text { Post }\end{array}\right.$ & $\begin{array}{l}23.0 \\
\text { UD }\end{array}$ & $\begin{array}{l}23.5 \\
10.9\end{array}$ & $\begin{array}{r}11.8 \\
2.8\end{array}$ & 20.5 & $\begin{array}{r}76 \\
\text { UD }\end{array}$ & $\begin{array}{l}70 \\
50\end{array}$ & UD & 53 \\
\hline 7. & 50 & $\mathrm{~F}$ & $\left\{\begin{array}{l}\text { Pre } \\
\text { Post }\end{array}\right.$ & $\begin{array}{l}29.0 \\
\text { UD }\end{array}$ & 28.0 & 23.5 & 41.5 & $\begin{array}{l}110 \\
\text { UD }\end{array}$ & $\begin{array}{l}95 \\
59\end{array}$ & $\begin{array}{r}134 \\
24\end{array}$ & $\begin{array}{r}730 \\
29\end{array}$ \\
\hline 8. & 25 & $\mathbf{F}$ & $\left\{\begin{array}{l}\text { Pre } \\
\text { Post }\end{array}\right.$ & $\begin{array}{r}21.0 \\
1.9\end{array}$ & $\begin{array}{l}21.4 \\
11.2\end{array}$ & $\begin{array}{r}20.8 \\
3.2\end{array}$ & $\begin{array}{r}25.7 \\
6.5\end{array}$ & $\begin{array}{r}165 \\
\mathbf{U D}\end{array}$ & $\begin{array}{l}210 \\
115\end{array}$ & $\begin{array}{l}215 \\
\text { UD }\end{array}$ & $\begin{array}{l}580 \\
160\end{array}$ \\
\hline 9. & 34 & F & $\left\{\begin{array}{l}\text { Pre } \\
\text { Post }\end{array}\right.$ & $\begin{array}{r}23.9 \\
9.1\end{array}$ & $\begin{array}{l}23.5 \\
16.5\end{array}$ & $\begin{array}{l}19.0 \\
\text { UD }\end{array}$ & $\begin{array}{r}45.5 \\
6.5\end{array}$ & $\begin{array}{l}59 \\
32\end{array}$ & $\begin{array}{l}57 \\
76\end{array}$ & $\begin{array}{l}64 \\
22\end{array}$ & $\begin{array}{r}305 \\
\mathbf{3 3}\end{array}$ \\
\hline 10. & 32 & $\mathbf{M}$ & $\left\{\begin{array}{l}\text { Pre } \\
\text { Post }\end{array}\right.$ & $\begin{array}{l}37.1 \\
\text { UD }\end{array}$ & $\begin{array}{l}33.3 \\
12.9\end{array}$ & $\begin{array}{r}39.0 \\
3.1\end{array}$ & $\begin{array}{r}61.5 \\
6.2\end{array}$ & $\begin{array}{r}115 \\
19\end{array}$ & $\begin{array}{r}115 \\
53\end{array}$ & $\begin{array}{l}74 \\
28\end{array}$ & $\begin{array}{r}280 \\
53\end{array}$ \\
\hline
\end{tabular}

UD: Undetectable

ingを3 例に認めたが，残り 7 例はまったく正常のトル コ鞍を示した。これら症例に $2 \mathrm{~mm}$ 間隔で正側両面の卜 ルコ鞍多断層撮影を施行してみると，鞍底の限局性陷凹
など, microadenoma を示唆する所見を 2 例に認めた。 気脳写断層撮影は全例に施行したが，軽度のトルコ鞍隔 膜の上方伸展を 1 例（Case 1) に認めたのみであり，下 


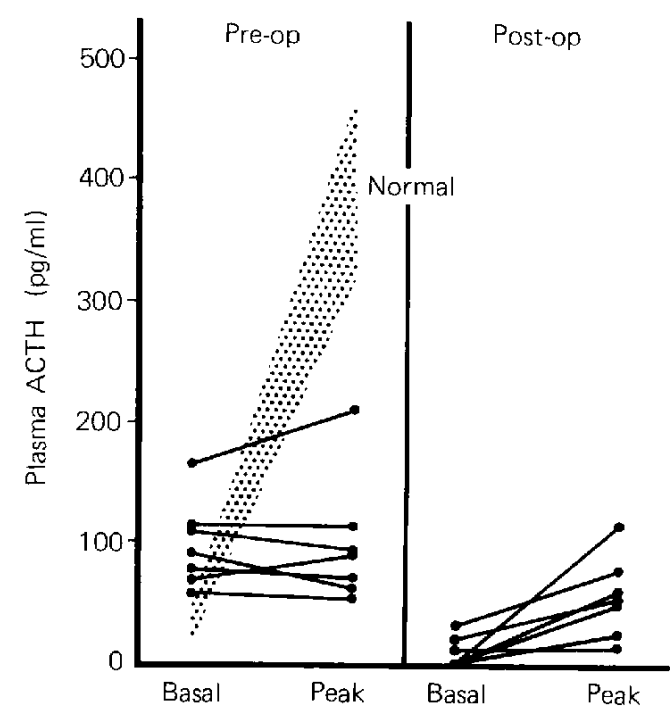

Fig. 2 Plasma ACTH responses to insulin hypoglycemia before and after surgery.

垂体腺腫の診断にはほとんど無効であった（Fig.1）.時 にトルコ鞍隔膜が逆に下方一軽度の陷凹を示す症例もあ り，結果的にみてこのような場合には microadenoma で もきわかて小さなものであり，発見困難な場合が多かっ た。脳血管撮影は，拡大撮影や断層撮影も一部症例に応 用して施行してみたが， microadenoma の存在克示㖫す る所見は 1 例も認められなかった。

\section{I 手術所見亡治療成績}

\section{1. 手術所見}

経蝶形骨洞法により手術を施行したクッシング病 10 症例の全例で，下垂体腺腫を確認し，これを摘除した

(Fig. 1). この5ち, 症例 $1,2,3,8 \sigma 4$ 症例では, 直 径 $10 \mathrm{~mm}$ 前後かまたはそれ以上でトルコ鞍内をほぼ充満 する macroadenoma であり，発見は容易であった，残り 6 症例では, 腺腫の直径 $3 \sim 7 \mathrm{~mm}$ 前後の microadenoma であった.このうら, 症例 7 との2 例では, 下 垂体前葉の中央底面部に腺腫が一部直接露出して扝り， 容易に発見できた。 なお症例 7 の場合では，腺随は中央 部から右側の lateral wing 内一かなり梁く側方伸展して いた. 症例 4，6，1003 例では，下垂体表面はまったく 正常であり，これに切開を加え慎重に検索した結果，前 莱組織内に完全に埋没した腺腫が確認された。

特に症例10では, 左側の lateral wing 内に腺腫が偏在 して掞り，発見困難であった。 また症例 5 では，術棜の

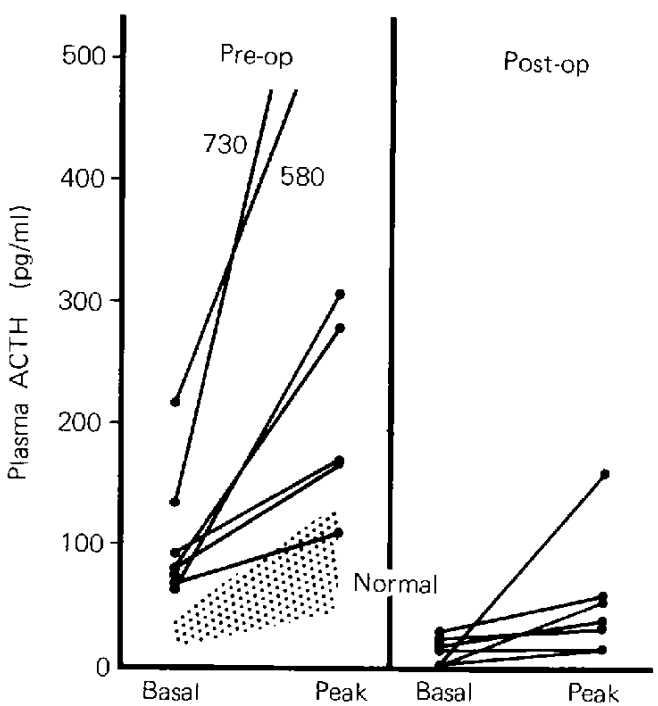

Fig. 3 Plasma ACTH responses to 8-lysine vasopressin before and after surgery.

トルコ鞍断層写真にて鞍底から後床突起八の移行部にわ ずかの陷凹壳認めたが，イメージテレビで点検しつつ同 部を慎重に梌索した結果，直径 $3 \mathrm{~mm}$ のきわかて小さな 腺腫が発見できた，術中，少量の髄液流出を症例 8 で認 めた. この症例在除き, 全例とも腺腫摘除部位を無水了 ルコールで $5 \sim 10$ 分間十分に洗滌した.

\section{2. 治療成䋶}

10例中 1 例（Case 4) を除き，腺腫摘除後 $2 \sim 3$ 力月 以内に満月様顔貌，中心性肥満の減少や皮膚色素沈着の 消失なと，臨床症状の著しい改善を諗的た。また術前 4 例に無月経党認めたが，全例とも少後数力月以内に規則 的な月経再来を得たこれらの症例で仕はとんどの場 合，術直後より高度の副腎皮質機能不全症状来し，副 腎皮質ホルモンの持続投与を必要とした。なお，10例中 7 例では術後 1 年以内に中断しえたが，残り3例では引 続き経口服用中である，腺腫摘除が不完全であったと推 察される1例（Case 4) では，明らかな症状改善が得ら れず，術後の副腎皮質機能不全症状も軽微であった。

\section{N 術後の内分泌機能}

\section{1. 視床下部一下垂体一副堅皮質系機能}

下垂体腺腫摘除後 $3 \sim 6$ 週の時点で術後の内分泌検査

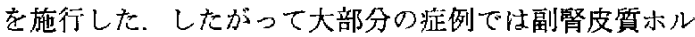
モンを服用中であるが，検查施行前少なくとも24時間㤬 一旦服用を中此した。検查項目としては血墏 $\mathrm{ACTH}$ 
Table 2 Pre- and Post-operative responses of anterior pituitary hormones.

\begin{tabular}{|c|c|c|c|c|c|c|c|c|c|c|c|}
\hline \multirow{3}{*}{$\begin{array}{c}\text { Patients } \\
\text { No. }\end{array}$} & \multirow{3}{*}{$\begin{array}{l}\text { Pre-OP } \\
\text { Post-OP }\end{array}$} & \multirow{2}{*}{\multicolumn{2}{|c|}{$\frac{\text { Insulin }}{\mathrm{GH}(\mathrm{ng} / \mathrm{m} l)}$}} & \multicolumn{4}{|c|}{ TRH test } & \multicolumn{4}{|c|}{ LH-RH test } \\
\hline & & & & \multicolumn{2}{|c|}{$\mathrm{TSH}(\mu \mathrm{U} / \mathrm{m} l)$} & \multicolumn{2}{|c|}{$\mathrm{PRL}(\mathrm{ng} / \mathrm{m} l)$} & \multicolumn{2}{|c|}{$\mathrm{LH}(\mathrm{mIU} / \mathrm{m} l)$} & \multicolumn{2}{|c|}{$\mathrm{FSH}(\mathrm{mIU} / \mathrm{ml})$} \\
\hline & & Basal & Peak & Basal & Peak & Basal & Peak & Basal & Peak & Basal & Peak \\
\hline 1. & $\left\{\begin{array}{l}\text { Pre } \\
\text { Post }\end{array}\right.$ & $\begin{array}{l}0.8 \\
5.0\end{array}$ & $\begin{array}{l}0.9 \\
5.0\end{array}$ & $\begin{array}{l}5.0 \\
4.5\end{array}$ & $\begin{array}{l}8.5 \\
9.5\end{array}$ & $\begin{array}{l}11.7 \\
10.5\end{array}$ & $\begin{array}{l}30.0 \\
61.0\end{array}$ & $\begin{array}{r}6.0 \\
14.0\end{array}$ & $\begin{array}{l}10.0 \\
31.0\end{array}$ & $\begin{array}{r}10.0 \\
9.0\end{array}$ & $\begin{array}{l}13.0 \\
12.0\end{array}$ \\
\hline 2. & $\left\{\begin{array}{l}\text { Pre } \\
\text { Post }\end{array}\right.$ & $\begin{array}{l}1.9 \\
2.7\end{array}$ & $\begin{array}{r}2.0 \\
10.6\end{array}$ & $\begin{array}{l}0.6 \\
7.0\end{array}$ & $\begin{array}{r}1.7 \\
34.5\end{array}$ & 21.5 & & $\begin{array}{l}32.0 \\
97.0\end{array}$ & $\begin{array}{l}114.0 \\
332.0\end{array}$ & $\begin{array}{r}80.0 \\
100.0\end{array}$ & $\begin{array}{l}130.0 \\
174.0\end{array}$ \\
\hline 3. & $\left\{\begin{array}{l}\text { Pre } \\
\text { Post }\end{array}\right.$ & $\begin{array}{l}1.5 \\
3.3\end{array}$ & 5.0 & $\begin{array}{l}5.0 \\
2.5\end{array}$ & $\begin{array}{l}10.5 \\
12.5\end{array}$ & $\begin{array}{l}22.7 \\
47.0\end{array}$ & $\begin{array}{r}38.7 \\
124.0\end{array}$ & $\begin{array}{l}5.0 \\
7.0\end{array}$ & $\begin{array}{r}7.0 \\
31.0\end{array}$ & $\begin{array}{l}8.0 \\
5.0\end{array}$ & $\begin{array}{l}8.0 \\
8.0\end{array}$ \\
\hline 4. & $\left\{\begin{array}{l}\text { Pre } \\
\text { Post }\end{array}\right.$ & $\begin{array}{l}2.2 \\
1.4\end{array}$ & $\begin{array}{l}2.2 \\
2.7\end{array}$ & $\begin{array}{l}3.2 \\
3.0\end{array}$ & $\begin{array}{l}6.2 \\
4.0\end{array}$ & $\begin{array}{l}13.5 \\
14.5\end{array}$ & $\begin{array}{l}51.5 \\
49.0\end{array}$ & $\begin{array}{l}0.6 \\
5.0\end{array}$ & $\begin{array}{r}3.9 \\
12.0\end{array}$ & $\begin{array}{l}1.0 \\
3.0\end{array}$ & $\begin{array}{r}3.1 \\
14.0\end{array}$ \\
\hline 5. & $\left\{\begin{array}{l}\text { Pre } \\
\text { Post }\end{array}\right.$ & $\begin{array}{l}1.2 \\
1.9\end{array}$ & $\begin{array}{l}1.3 \\
3.4\end{array}$ & $\begin{array}{l}1.0 \\
1.0\end{array}$ & $\begin{array}{l}2.5 \\
4.0\end{array}$ & $\begin{array}{r}9.3 \\
22.5\end{array}$ & $\begin{array}{l}78.0 \\
46.0\end{array}$ & $\begin{array}{r}8.3 \\
44.0\end{array}$ & $\begin{array}{r}9.8 \\
128.0\end{array}$ & $\begin{array}{l}14.1 \\
45.0\end{array}$ & $\begin{array}{l}18.4 \\
65.0\end{array}$ \\
\hline 6. & $\left\{\begin{array}{l}\text { Pre } \\
\text { Post }\end{array}\right.$ & $\begin{array}{l}1.4 \\
1.1\end{array}$ & $\begin{array}{l}2.8 \\
6.2\end{array}$ & $\begin{array}{l}1.5 \\
2.0\end{array}$ & $\begin{array}{l}10.5 \\
20.0\end{array}$ & $\begin{array}{l}22.5 \\
51.5\end{array}$ & $\begin{array}{r}62.0 \\
111.0\end{array}$ & $\begin{array}{r}3.0 \\
14.0\end{array}$ & $\begin{array}{r}81.0 \\
292.0\end{array}$ & $\begin{array}{r}14.0 \\
9.0\end{array}$ & $\begin{array}{l}38.0 \\
22.0\end{array}$ \\
\hline 7. & $\left\{\begin{array}{l}\text { Pre } \\
\text { Post }\end{array}\right.$ & $\begin{array}{l}1.9 \\
2.4\end{array}$ & $\begin{array}{l}2.4 \\
5.3\end{array}$ & $\begin{array}{l}6.5 \\
4.5\end{array}$ & $\begin{array}{l}7.5 \\
9.0\end{array}$ & $\begin{array}{l}25.0 \\
36.1\end{array}$ & $\begin{array}{r}83.0 \\
103.5\end{array}$ & $\begin{array}{r}3.0 \\
24.0\end{array}$ & $\begin{array}{r}9.0 \\
57.0\end{array}$ & $\begin{array}{r}4.0 \\
36.0\end{array}$ & $\begin{array}{l}15.0 \\
41.0\end{array}$ \\
\hline 8. & $\left\{\begin{array}{l}\text { Pre } \\
\text { Post }\end{array}\right.$ & $\begin{array}{l}2.8 \\
3.0\end{array}$ & $\begin{array}{r}7.5 \\
14.0\end{array}$ & $\begin{array}{l}\text { UD } \\
3.0\end{array}$ & $\begin{array}{r}3.0 \\
11.5\end{array}$ & $\begin{array}{r}7.3 \\
27.8\end{array}$ & $\begin{array}{l}47.2 \\
85.0\end{array}$ & $\begin{array}{l}20.0 \\
14.0\end{array}$ & $\begin{array}{r}101.4 \\
52.0\end{array}$ & $\begin{array}{l}15.8 \\
10.0\end{array}$ & $\begin{array}{l}17.7 \\
13.0\end{array}$ \\
\hline 9. & $\left\{\begin{array}{l}\text { Pre } \\
\text { Post }\end{array}\right.$ & $\begin{array}{l}0.8 \\
1.4\end{array}$ & $\begin{array}{r}3.9 \\
11.8\end{array}$ & $\begin{array}{l}\text { UD } \\
4.5\end{array}$ & $\begin{array}{r}4.0 \\
19.0\end{array}$ & $\begin{array}{l}15.8 \\
16.5\end{array}$ & $\begin{array}{l}61.0 \\
84.0\end{array}$ & $\begin{array}{r}4.0 \\
15.0\end{array}$ & $\begin{array}{l}31.0 \\
42.0\end{array}$ & $\begin{array}{l}10.0 \\
17.0\end{array}$ & $\begin{array}{l}27.0 \\
27.0\end{array}$ \\
\hline 10. & $\left\{\begin{array}{l}\text { Pre } \\
\text { Post }\end{array}\right.$ & $\begin{array}{l}1.5 \\
1.8\end{array}$ & $\begin{array}{r}1.3 \\
11.7\end{array}$ & $\begin{array}{l}\text { UD } \\
4.0\end{array}$ & $\begin{array}{l}\text { UD } \\
11.0\end{array}$ & 19.4 & 53.5 & $\begin{array}{r}9.4 \\
35.0\end{array}$ & $\begin{array}{l}28.3 \\
95.0\end{array}$ & $\begin{array}{l}12.6 \\
15.0\end{array}$ & $\begin{array}{l}18.4 \\
23.0\end{array}$ \\
\hline Mean & Pre-OP & $\begin{array}{r}1.6 \\
+0.6\end{array}$ & $\begin{array}{r}2.7 \\
\pm 1.9\end{array}$ & $\begin{array}{r}2.3 \\
\pm 2.3\end{array}$ & $\begin{array}{r}5.4 \\
\pm 3.5\end{array}$ & $\begin{array}{r}16.0 \\
\pm 6.3\end{array}$ & $\begin{array}{r}56.5 \\
\pm 17.3\end{array}$ & $\begin{array}{r}6.9 \\
\pm 5.9^{\mathrm{a}}\end{array}$ & $\begin{aligned} & 37.5 \\
\pm & 35.7^{\mathrm{a}}\end{aligned}$ & $\begin{array}{l}10.2 \\
\pm 4.5^{\mathrm{a}}\end{array}$ & $\begin{array}{r}17.9 \\
\pm 10.9^{\mathrm{a}}\end{array}$ \\
\hline \pm S.D. & Post-OP & $\begin{array}{r}2.3 \\
\pm 1.1\end{array}$ & $\begin{array}{r}7.9 \\
\pm 3.9\end{array}$ & $\begin{array}{r}3.6 \\
\pm 1.6\end{array}$ & $\begin{array}{r}13.5 \\
+8.6\end{array}$ & $\begin{array}{r}26.7 \\
\pm 13.2\end{array}$ & $\begin{array}{r}79.7 \\
\pm 27.2\end{array}$ & $\begin{array}{r}14.9 \\
+9.0^{\mathrm{a}}\end{array}$ & $\begin{array}{c}79.3 \\
+90.1^{a}\end{array}$ & $\begin{array}{r}9.7 \\
\pm 4.6^{\mathrm{a}}\end{array}$ & $\begin{array}{r}17.0 \\
\pm 6.5^{\mathrm{a}}\end{array}$ \\
\hline P Value & & $<0.05$ & $<0.01$ & NS & $<0.05$ & $<0.02$ & NS & $<0.05$ & $<0.05$ & NS & NS \\
\hline
\end{tabular}

UD: Undetectable, NS : Not significant

a Postmenopausal patients (No. 2, 5, 7) were excluded

よびューチゾールの日内変動括よびインシュリン低血糖 刺激と LVP に対する反応を重点的に测定した（Table

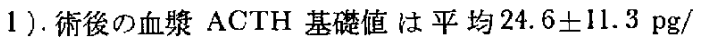
$\mathrm{m} l$ となり, 術前の平均值 $135.6 \pm 27.5 \mathrm{pg} / \mathrm{m} l$ に比し著し く低下した。 9 例中 4 例では测定限界 $(>10 \mathrm{pg} / \mathrm{m} l)$ 以 下となった，インシュリン低血糖刺激に対して術前は全 例とも無反灾であったが，術後は7例中 6 例で血獎 $\mathrm{AC}$ $\mathrm{TH}$ の明らかな分泌増加反店認ぬた（Table 1, Fig. $2)$.これら症例の平均基硔值は8. $5 \pm 5.6 \mathrm{pg} / \mathrm{ml}(\mathrm{M} \pm \mathrm{S}$. E.)であり，インシュリン負荷後の頂值は $62.7 \pm 12.6$ $\mathrm{pg} / \mathrm{ml}$ と明ら汃な增加反応を示した，一方，LVPに対す る術前の著しい血漿 ACTH 分泌増加反応は，腺腫摘除 に伴い明らかな減弱を示すか，完全に無反応となった

(Fig. 3，4). 字なから，LVP 投与前の平均基礎值 12.3 $\pm 5.6 \mathrm{pg} / \mathrm{ml}$ に対し, 頂值は57.0 $\pm 21.4 \mathrm{pg} / \mathrm{ml}$ であった

(Table 1)，術直後の日内変動に関してはほとんどの症 例が持続的低值を示すものが多く，明らかな日内りズム
の出現を認めなかったが，術後 6 力月以上にわたって経 過観察しえた 5 例では全例とも明らかな日内リズムの出 現が颉められた（Fig. 5)。

\section{2. 他の下垂体前葉機能}

(1) GH：全症例に打ける術後の血漿 $\mathrm{GH}$ 基整值は平 均 $2.3 \pm 1.1 \mathrm{ng} / \mathrm{m} l(\mathrm{M} \pm \mathrm{S} . \mathrm{D}$.$) であり，術前の平均值$ $1.6 \pm 0.6 \mathrm{ng} / \mathrm{ml}$ より軽度ながらも増加した.さらに、イ ンシュリン負荷後の血漿 $\mathrm{GH}$ の頂值汢平均7.9土3.9ng/ $\mathrm{m} l$ となり，術前の平均值 $2.7 \pm 1.9 \mathrm{ng} / \mathrm{m} l$ に比し有意の 増加反応を認めた（p<0.01） (Table 2).また，術前は 1 例む10 $\mathrm{ng} / \mathrm{m} l$ 以上の頂值を示さなかったが，術後は 4 例で $10 \mathrm{ng} / \mathrm{ml}$ 以上の明らかな $\mathrm{GH}$ 分泌反怘を認めた (Fig. 6).

(2) TSH：術前高頻度に諗められた TSH 分泌障害 は，下垂体腺腫摘除に伴い著しく改善した。すなわち術 前では10例中 3 例でTSH 基礎値は測定不能であった が，術後は全例とも測定可能となり，全体の平均值も術 


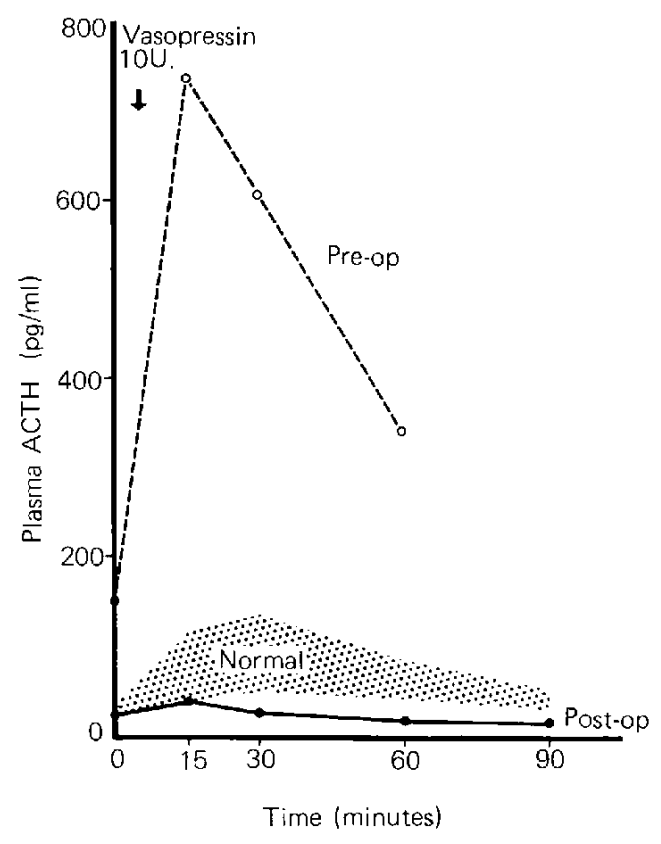

Fig. 4 Plasma ACTH responses to 8-lysine vasopressin in Case 7. Note complete disappearance of preoperative conspicuous response after selective adenomectomy.

前の2. $3 \pm 2.3 \mu \mathrm{U} / \mathrm{m} l(\mathrm{M} \pm$ S. D. $)$ 上り術後は $3.6 \pm 1.6$ $\mu \mathrm{U} / \mathrm{m} l$ と増加した。 また TRH負荷後の頂值む術前の $5.4 \pm 3.5 \mu \mathrm{U} / \mathrm{m} l$ より $17.5 \pm 8.6 \mu \mathrm{U} / \mathrm{m} l$ と著しい増加を 示した $(p<0.05)$ (Table 2, Fig. 6).

(3) LH, FSH：閉経後症例（Case 2, 5, 7) 除 く 術後の血墏 LH 拉上びFSH の平均基䂣值は, それぞれ $14.9 \pm 9.0,9.7 \pm 4.6 \mathrm{mIU} / \mathrm{ml}(\mathrm{M} \pm \mathrm{S} . \mathrm{D}$.$) であった.$ また，LH-RH 負荷後の頂值仕それぞれ79.3 $17.0 \pm 6.5 \mathrm{mIU} / \mathrm{m} l$ であり, 術後の $\mathrm{LH}$ 基䃈値, 頂値と も術前徂に比し有意の增加を認めた $(\mathrm{p}<0.05)$ (Table 2). 術前高度の LH 分泌障害を認好た症 例 (Case 1 , 3，6，10）では，特に著しい改善を認めた (Fig. 7). また，閉経後症例（Case 2，5，7）についてみても，術 後の LH, FSH 分泌機能は，基䂣值，頂值とも著しい改 善が認められた。これらの結果は，術前の無月経症例が 術後は寸べて規則的な月経再来を回復した臨床結果とも 一致する。

(4) PRL：術後の血中 PRL 基脴值むうび TRH 負荷 後の頂値仗それぞれ $26.7 \pm 13.2,79.7 \pm 27.2 \mathrm{ng} / \mathrm{ml}$ であ り，術前に比し軽度の増加在認めた。 3 例 (Case 3，6, 7) では，術前の血中 PRL 值は正常範 囲内であった が, 術後恃軽度 $の$ 分泌增加 (平均 $44.9 \mathrm{ng} / \mathrm{ml}$ ) 示した。
Diurnal rhythm of plasma ACTH \& cortisol

3 mos $\overline{\mathrm{p}}$ op

(34yrs,F.)
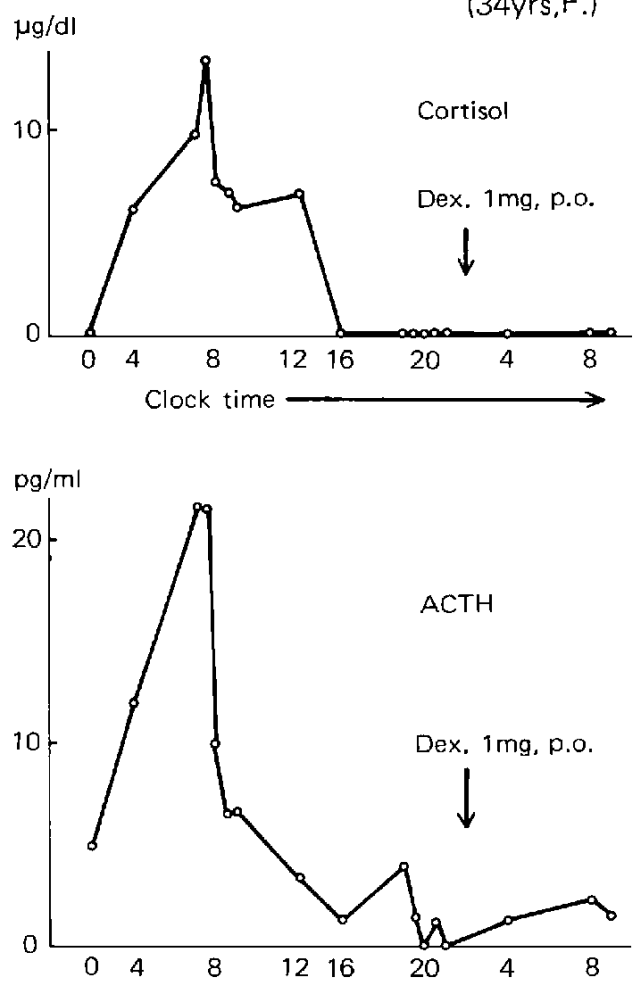

Fig. 5 Normal diurnal rhythmicity of plasma cortisol and ACTH returning within 3 months after surgery in Case 9. Normal suppression of plasma cortisol and ACTH by dexamethasone is also evident.

ただしいずれの症例も乳漏症の発症怯認㱛ていない，

\section{$\mathrm{V}$ 考 察}

神経放射線学的に microadenoma を診断するに恃自ら 限界があり，現時点ではトルコ鞍の形態異常の有無にか かわらず，内分泌学的にクッシング病の診断が確定した 総ての症例が経蝶形骨洞手術の刘象となりうる214)。我 々の印象では，トルコ鞍の ballooning とか鞍底の変化を 認める場合には比较的大きな腺腫の可能性が高く, 骨変 化の部位に一致して腺腫が直接表面に一部露出したり， あるいはその直下に存在し，腺腫を比較的容易に確琹で きる場合が多い：こ机に反し，まったく正常なトルコ鞍 を示し，しかもトルコ鞍㹈膜が下方に concaveしている 場合には腺腫はきわめて小さく，乙かも正常下垂体組織 内纪埋没している可能性が高い. ACTH 産生腺䐺は, 主 


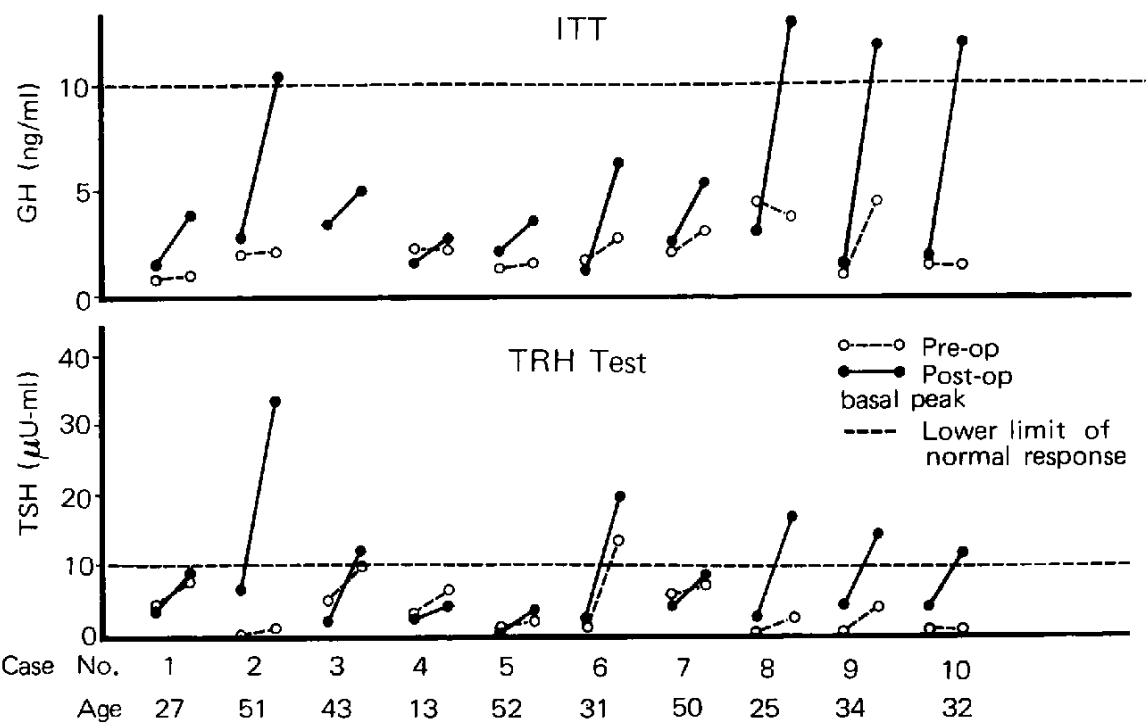

Fig. 6 Plasma GH responses to insulin hypoglycemia and TSH responses to TRH before and after surgery. GH responses were normalized in four cases after surgery.

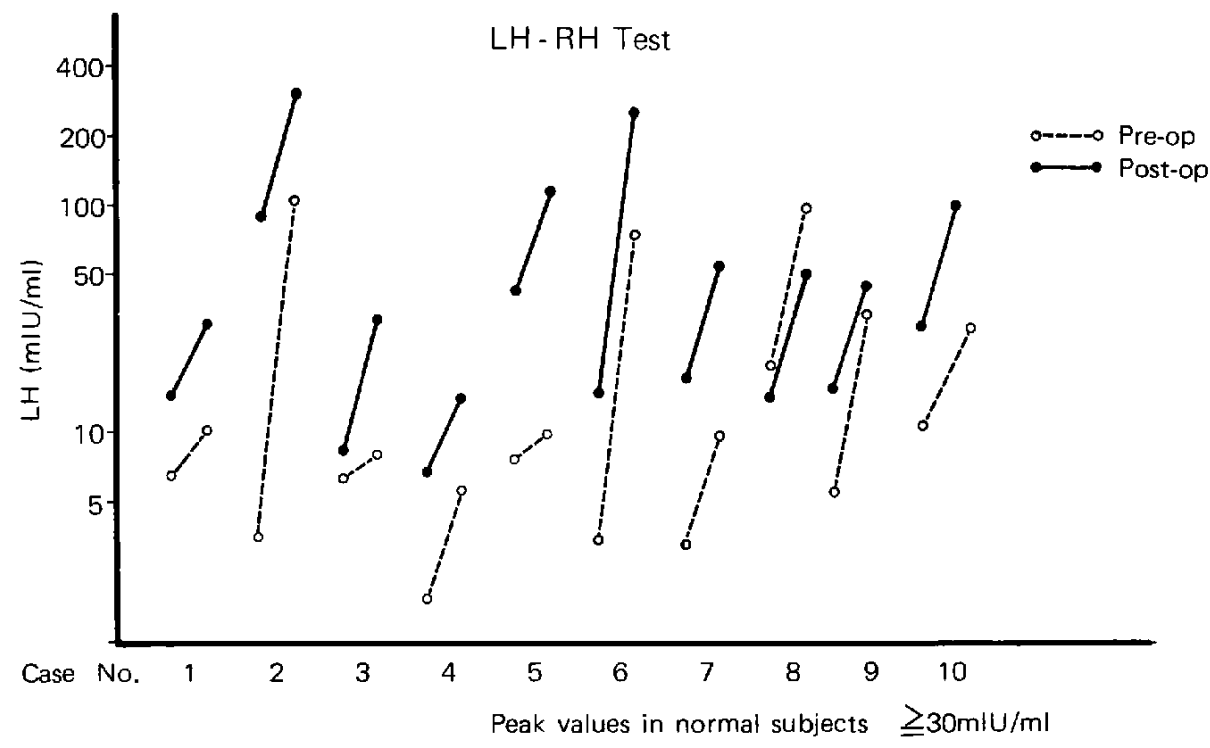

in postmenopausal women $\geqq 140 \mathrm{mlU} / \mathrm{ml}$

Fig. 7 Plasma LH responses to LH-RH.

として中間葉下端部の正中線上に存在するといわれる $\not j$, Wilsonらの報告と同様に ${ }^{143}$, 我々も腺腫が側方伸展 を示したり，一側の lateral wing 内に偏在する症例在経 験した. したがって腺腫確認が困難な場合には，トルコ 鞍内を幔なく捜查する必要がある，時に值径が $1 \mathrm{~mm}$ 以 下ときわめて小さな腺腫も経験されており，このような 場合にはたよえ手術用影微鏡下でも肉眼的に確認するこ
とは困難であり, 病理組織学的検查結果在待つか, 術後 の臨床症状や内分泌所見より判断せざるをえない場合も 存在する. 一般に microadenoma の完全摘出の可能性沬 大であるが，腺腫が下垂体被膜に直接接して存在する場 合には，microadenoma の段階ですでに被膜内浸潤をき たしらるものであり ${ }^{10)}$, 不完全治療あるいは再発の主た る原因となりらる。これに対する対策としても，腺腫摘 
除後アルコールで十分洗滌するこ上はある程度有効であ ると推察される

腺腫摘除に伴い血中 ACTH, コーチゾールの過剩分泌 は寸みやか消失するのみならず，非とんどの場合副㹂 皮質機能不全認的。. 下垂体前葉組織を一分に残存し えたにもかかわらずこの上らな分泌不全を来す理由とし ては，才で報告したごとぐ，残存組織中のACTH 分 泌細胞が Crooke 変性等の形熊的異常や内分泌機能障害

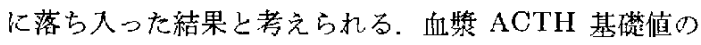
低下のみでなく，LVPに対寸る術前の著しい分泌增加反 応もほとんど完全に消失することより，残存組織中のA $\mathrm{CTH}$ 分泌予備能すきわ減少してい万ものと推察さ れる. 須田 ${ }^{13)}$, 鎮口 ${ }^{12)}$ ら法手術時一部採取した非腺腫組 織中の ACTH, $\beta$-endorphin 含有量を測定し, 共に正常 值に比し著しく低下している事実昰認めた，

したがって手術前の状況下では，非腺㾝組織中の $\mathrm{AC}$ $\mathrm{TH}$ 分泌細胞はホルモン合成，分泌の抑制作用強く受 けていたものと推察される. 低血糖刺激汇対するACTH 分泌增加反応は視床下部よりの CRF 分泌在介寸るとさ れているが，この刺激に対してクッシング病の場合ほと んど無反応である ${ }^{335)}$ ，しかるに，腺腫摘除直後から軽度 ながらも正常者と同様の増加反応を認めた。束た， $\mathrm{AC}$ TH やコーチジールの日内リズムも出現した，以上の結 果を総合寸ると，腺腫発生の原因㤌未だ不明であるが， 少なくとも腺腫発生後では視床下部拉よびその上位中枢 の機能光進による CRF 分泌堌加屾考えられず，逆にC $\mathrm{RF}$ 分泌抑制が推察される ${ }^{12}$.さらには，腺腫摘除後の $\mathrm{ACTH}$ 分泌動態上りみて，視床下部の CRF分泌嘰能の 改善が示唆される。ただ残存組織中のACTH 分泌細 胞は，手術時すでに高度の機能障害を受けており，AC TH 分泌機能が正常に復するには，術後数力月から年余 を要するものと考完られる11.

下垂体腺腫摘除により，GH，TSH，LHなど他のホル モン分必機能障害も著しく改善したが，その回復速度上 りみて,これらの分泌障害は ACTH 分泌障害に比し, より可逆性の高いるのと考えられる.ただしこれらホル モンの5ちでも，GH 分泌機能の改善が弱い印象を受 け，各ホルモン間における分泌機能障害の程度と乞の回 復過程沬多少異なるるのと思われる。 内因性, 外因性を 問わず，過剩のコーチゾール柱として下垂体前葉に作 用して、これらのホルモン分泌常障する事実が知られ ている1477)、 しかしながら視床下部の TRH 分泌がコ ーチゾールにより抑制される実䮖結果も報告されてお $り^{8)} ，$ 一部はコーチゾールによる視床下部の機能障害む 考えられるッ゙. したがって術後のホルモン分泌機能の改
善は，視床下部一下垂体系機能に対するコーチダールの 抑制作用の解除によるものと結論される。

以上，我々注クッシング病に対する下垂体腺腫摘除術

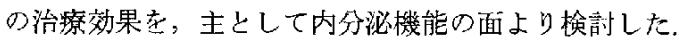
その結果，単に ACTH 過剩分泌のみならず，他の下垂 体前葉ホルモン分泌機能障害も積極的に改善させらる事 実が確認された。また分泌機能動態の释時的観察結果 より，下垂体腺腫摘除によりクッシング病を完治させう る可能性も大であると推察される。

本研究は, 第37回日本腷神経外科学会総会(1978年10 月）で発表した。

本研究は，厚生省視休下部下垂体機能障害調盉研究費 補助金によった。

\section{文献}

1) Boccuzzi, G., Angeli, A., Brsbocci, D., Fonzo, D, Gaidano, G. P. \& Ceresa, F.: Effect of synthetic luteinizing hormone releasing hormone (LH-RH) on the release of gonadotropins in Cushing's disease. J Clin Endocrinol Metab 40: 892-895, 1975

2) HARdY, J.: Microsurgical exploration of a normal sella turtica for a microadenoma. Presented at 2nd European Workshop on Pituitary Adenomas. Paris, September, 1979

3) Imura, H., Nakai, Y., Matsukura, S. \& YoshiмI, T.: Control of ACTH secretion in normal subjects and patients with Cushing's disease. Proc of 6th Asia \& Oceania Congress of Endocrinol 1: 92-97, 1977

4) Krifger, D. T. \& Glick, S. M.: Growth hormone and xortisol responsiveness in Cushing's syndrome. Relation to a possible central nervous system etiology. Am J Med 52: 25-40, 1972

5) Krieger, D. T. \& Luria, M.: Plasma ACTH and cortisol responses to TRF, vasopressin or hypoglyccmia in Cushing's disease and Nelson's syndrome. J Clin Endocrinol Metab 44: 361-368, 1977

6) 桑山明夫, 景山直樹, 中根藤七，高野橋正好， 岡田力, 蟹江規雄, 原 䈯, 富田明夫: タッ シング病に対する経鼻的手術. Neurol Med Chir (Part II) 18: 279-285, 1978

7) Luton, J. B., Thieblot, P., Valke, J. C., Maholdeau, A. \& Bricaire, H.: Reversible gonadotropin deficiency in male Cushing's disease. J Clin Endocrinol Metab 45: 488-495, 1977

8) 满間照典, 鰐部春淞, 野木森㣚: 間 脑下垂体 甲状腺系調節機構に及ぼすデキサメサゾンの影 響. 日内泌誌 $54: 339,1978$ 
9) Otsuki, M.,Dakoda, M. \& Baba, S.: Influence of glucocorticoids on TRF-induced TSH response in man. $J$ Ctin Endocrinol Metab 36: 95102,1973

10) Peillon, F.: Personal communication

I1) Salassa, R. M., Laws, E. R., Carpenter, P. C. \& NorthcutT, R. C.: Transsphenoidal removal of pituitary microadenoma in Cushing's disease. Mayo Clin Proc 53: 24-28, 1978

12）鎮目和夫：下垂体疾患の臨床。日内泌誌 68 : $1-14,1979$

13）須田俊宏, 阿部幸治, 若林一二, 出村 博,
出村黎子, 鎮目和夫: Cushing 病下垂体腫癔中 の ACTH, $\beta$-LPH, $\beta$-endorphin. 日内泌訫55: 403,1979

14) Wilson, C. B. \& Dempsey, L. C.: Transsphenoidal microsurgical removal of 250 pituitary adenomas. J Netrosurg 48: 13-22, 1978

15) Wilson, C. B., Tyrrell, B. J. \& Fitzgerald, P.: Treatment of Cushing's disease by transsphenoidal operation. Presented at annual meeting of the American Association of Neurological Surgeons. California, scientific manuscripts, 1979, pp 51-52 